\title{
Pemberdayaan Kader Posyandu dalam Deteksi Dini Kejadian Stunting di Desa Sidodadi Kecamatan Teluk Pandan Kabupaten Pesawaran
}

\author{
Sutrio*1, Usdeka Muliani², Yulia Novika $^{3}$ \\ 1,2,3Program Studi D3 Gizi, Politeknik Kesehatan Tanjung Karang, Indonesia \\ *e-mail: sutrio@poltekkes-tjk.ac.id ${ }^{1}$, inideka@yahoo.co.id ${ }^{2}{ }_{\text {_yulianovikaj@poltekkes-tik.ac.id }}^{3}$
}

\begin{abstract}
Abstrak
Pemerintah berusaha menanggulangi stunting dengan upaya intervensi gizi spesifik. Agar program tersebut dapat berjalan dengan efektif maka deteksi dini anak dengan stunting penting untuk dilakukan. Kader posyandu sebagai orang yang dekat dengan masyarakat dan merupakan perpanjangan tangan petugas kesehatan dalam hal menangani masalah kesehatan ibu dan anak yang terdapat di masyarakat bisa sangat strategis untuk dijadikan sebagai pihak yang bisa membantu mengatasi masalah stunting sesuai dengan kapasitasnya. Tujuan kegiatan pengabdian kepada masyarakat ini adalah untuk meningkatkan kesadaran kader mengenai stunting, menambah keterampilan kader dalam mendeteksi dini dan edukasi dalam pencegahan stunting di desa Sidodadi. Metode yang digunakan dalam kegiatan ini berupa pendekatan pemberdayaan masyarakat yang melibatkan masyarakat secara langsung sebagai subyek dan obyek pelaksanaan kegiatan pengabdian kepada masyarakat. Hasil kegiatan menunjukkan bahwa terdapat peningkatan pengetahuan kader tentang deteksi dini dan pencegahan stunting sebesar 25,42 poin dari 66,25 menjadi 91,67. Hasil uji $T$ diperoleh $p$ value $=0,000$ artinya secara statistik ada perbedaan yang signifikan tingkat pengetahuan antara sebelum dan sesudah pemberian pelatihan. Kegiatan ini juga terbukti mampu meningkatkan kesadaran kader mengenai stunting, kader mampu melakukan deteksi dini kejadian stunting dengan menggunakan KMS dan Grafik Pertumbuhan WHO serta mampu mengedukasi masyarakat tentang pencegahan stunting.
\end{abstract}

Kata Kunci: Deteksi, Dini, Kader, Posyandu, Stunting

\begin{abstract}
The government is trying to tackle stunting with specific nutrition interventions. In order for the program to run effectively, early detection of children with stunting is important. Posyandu cadres as people who are close to the community and are extensions of health workers in terms of dealing with maternal and child health problems in the community can be very strategic to serve as parties who can help overcome stunting problems according to their capacity. The purpose of this community service activity is to increase cadre awareness about stunting, increase cadre skills in early detection and education in stunting prevention in Sidodadi village. The method used in this activity is a community empowerment approach that involves the community directly as the subject and object of implementing community service activities. The results of the activity showed that there was an increase in the knowledge of cadres about early detection and prevention of stunting by 25.42 points from 66.25 to 91.67. T test results obtained $p$ value $=0.000$ means that statistically there is a significant difference in the level of knowledge between before and after the training. This activity has also been proven to be able to increase cadre awareness about stunting, cadres are able to carry out early detection of stunting events using KMS and WHO Growth Charts and are able to educate the public about stunting prevention.
\end{abstract}

Keywords: Cadre, Detection, Early, Posyand, Stunting

\section{PENDAHULUAN}

Stunting merupakan bentuk masalah "kekurangan gizi kronik dan termanifestasi dalam bentuk gagal tumbuh yang dapat dimulai sejak dalam kandungan hingga anak berusia dua tahun. Stunting di dua tahun pertama kehidupan menimbulkan kerusakan yang irreversible, termasuk tinggi badan yang pendek di usia dewasa, hambatan perkembangan fungsi kognitif dan motorik, performans yang buruk di sekolah, serta gangguan metabolik saat dewasa (Victora et al, 2008; Development Initiatives, 2018). Selain itu, menurut UNICEF Tahun 2018, stunting dapat menyebabkan penurunan daya saing SDM, serta secara ekonomi menurut World Bank Tahun 2016 dapat mengakibatkan potensi kerugian 2-3\% dari GDP per tahun (Bappenas, 2019). 
Tingginya angka stunting pada balita sangat berkaitan erat dengan kondisi yang terjadi dalam waktu yang lama seperti kemiskinan, perilaku hidup bersih dan sehat yang kurang, kesehatan lingkungan yang kurang baik, pola asuh yang kurang baik dan rendahnya tingkat pendidikan. UNICEF (2013) mengungkapkan bahwa stunting tidak disebabkan hanya oleh satu faktor tunggal melainkan disebabkan oleh banyak faktor yang terkait satu sama lain. Tiga faktor utama yang menyebabkan stunting adalah asupan gizi tidak seimbang, adanya riwayat penyakit infeksi, dan berat badan lahir rendah.

Beberapa faktor tersebut berimplikasi dengan kejadian stunting. Prevalensi stunting di Indonesia pada tahun 2013 sebesar 37,2\%, kemudian mengalami penurunan pada tahun 2018 menjadi 30,8\%. Walaupun mengalami penurunan, stunting masih menjadi masalah kesehatan masyarakat yang perlu ditangani karena prevalensinya melebihi $20 \%$. Salah satu daerah provinsi yang menjadi sorotan masalah gizi stunting adalah Lampung dengan prevalensi stunting tahun 2018 sebesar 27,3\%. Prevalensi status gizi balita stunting di Kabupaten Pesawaran berdasarkan hasil Riset Kesehatan Dasar (Riskesdas) 2018 menunjukkan penurunan sebesar 23,31\% selama periode 5 tahun terakhir, dimana jika pada 2013 sebesar dari 50,8\%, kini menjadi 27,49\% di tahun 2018. Puskesmas Hanura termasuk dalam 3 (tiga) puskesmas dengan prevalensi stunting terbanyak di Kabupaten Pesawaran pada tahun 2020 yaitu 11\% setelah Puskesmas Maja dan Kota Dalam. Permasalahan stunting juga dipengaruhi oleh keadaan topografi seperti wilayah pesisir. Masyarakat yang tinggal di wilayah pesisir seharusnya memiliki peluang lebih besar mengkonsumsi makanan hewani tinggi protein seperti ikan karena akses dan ketersediaan yang cukup banyak, sehingga permasalahan gizi seperti stunting semestinya rendah. Kenyataannya, Desa Sidodadi merupakan desa pesisir di wilayah kerja Puskesmas Hanura dengan kejadian stunting terbanyak yaitu 42 balita.

Berdasarkan hasil wawancara dengan pihak Puskesmas Hanura, diketahui bahwa beberapa program yang pernah dilakukan terkait pencegahan stunting masih terfokus kepada ibu hamil yaitu penapisan ibu hamil kurang energi kronis (KEK) dan anemia, pemberian makanan tambahan (PMT) ibu hamil KEK atau anemia, dan adanya kelas ibu hamil dan ibu yang baru melahirkan terkait pemberian ASI eksklusif. Namun, Puskesmas Hanura belum melakukan sosialiasi terkait pemberian makan pada bayi dan anak (PMBA) yaitu khususnya dalam hal pemberian MP-ASI.

Selain gizi ibu saat hamil, pemberian makan pada bayi dan anak (PMBA) meliputi pemberian ASI eksklusif dan makanan pendamping ASI (MPASI) berdasarkan prinsip gizi seimbang merupakan salah satu cara pencegahan stunting dengan memenuhi kebutuhan gizi anak dalam 1000 hari pertama kehidupan. Hal ini terkait dengan belum adanya tenaga kesehatan di Puskesmas Hanura yang mengikuti pelatihan konseling menyusui dan pemberian makan pada bayi dan anak (PMBA).

Keterbatasannya tenaga kesehatan dan beban kerja belum sebanding dengan luasnya wilayah kerja di Hanura yang menyebabkan daya cakup pelayanan kesehatan belum optimal. Sehingga strategi pembangunan partisipatif adalah cara yang efektif untuk menangani masalah stunting ini. Dikatakan partisipatif karena bukan hanya pemerintah yang harus sadar dan beraksi, namun juga masyarakat harus sadar dan bergerak untuk menangani masalah ini. Untuk mendeteksi dan mencegah terjadinya stunting, diperlukan kerjasama dari berbagai stakeholder, terutama berkaitan dengan gizi dan kesehatan anak.

Pada hasil wawancara juga diketahui bahwa kader belum pernah disosialisasikan terkait pemberian makan pada bayi dan anak (PMBA). Bahkan, kegiatan penyegaran kader oleh Puskesmas Hanura terakhir kali dilakukan pada lima tahun yang lalu. Hasil observasi pada saat kegiatan penimbangan Posyandu di Desa Sidodadi menunjukkan bahwa para kader belum memplotkan hasil penimbangan pada lembar Kartu Menuju Sehat (KMS) anak, melainkan hanya mencatat berat badan, panjang badan dan usia bayi di buku kunjungan serta pengukuran panjang badan masih menggunakan meteran.

Kegiatan pemberdayaan kader di Desa Sidodadi terkait edukasi mengenai pencegahan stunting khususnya pemberian makan pada bayi dan anak (PMBA) penting untuk dilakukan sebagai bagian dari upaya promotif pencegahan stunting. Selain itu, kegiatan penyegaran kader juga penting dilakukan meliputi kegiatan posyandu yang dimulai dari pengukuran berat dan 
panjang badan serta plotting di KMS agar kader dapat membantu tenaga kesehatan untuk deteksi dini stunting. Kegiatan pemberdayaan dan penyegaran kader ini diharapkan untuk segera dapat dilakukan sebagai upaya promotif dan deteksi dini kejadian stunting sehingga kejadian stunting dan atau gangguan pertumbuhan dapat segera diatasi.

Stakeholder yang terkait tidak hanya tenaga kesehatan tetapi juga bisa tenaga kader. Kader posyandu sebagai orang yang juga dekat dengan masyarakat dan merupakan perpanjangan tangan petugas kesehatan dalam hal menangani masalah kesehatan ibu dan anak yang terdapat di masyarakat bisa sangat strategis untuk dijadikan sebagai pihak yang bisa membantu mengatasi masalah stunting sesuai dengan kapasitasnya. Kasus stunting terjadi biasanya karena kejadian ini tidak disadari sejak dini oleh masyarakat. Sehingga masyarakat perlu pemberdayaan agar tahu dan juga mengerti cara pencegahan dan tanda-tanda stunting. Apabila masyarakat tahu karakteristik stunting sejak dini, maka bisa segera dilakukan penanganan agar tidak menimbulkan dampak kesehatan jangka panjang.

Berdasarkan hal tersebut, tim Pengabdian Masyarakat Jurusan Gizi Politeknik Kesehatan Tanjung Karang bermaksud untuk melakukan intervensi kepada kader sebagai promotor pencegah dan deteksi dini stunting di Desa Sidodadi Kecamatan Teluk Pandan sebagai Desa dengan angka stunting yang masih terbilang tinggi di Wilayah Kerja Puskesmas Hanura. Kader akan diberikan edukasi, selanjutnya mereka diharapkan bisa menerapkan ilmu dan pengetahuannya ke masyarakat untuk mensosialisasikan stunting dan mampu melakukan pendeteksian kejadian stunting sejak dini.

\section{METODE}

Metode yang digunakan dalam kegiatan ini berupa pemberdayaan masyarakat yang menekankan keterlibatan masyarakat dalam keseluruhan kegiatan mulai dari perencanaan, pelaksanaan dan evaluasi program kegiatan dan Community development yaitu pendekatan yang melibatkan masyarakat secara langsung sebagai subyek dan obyek pelaksanaan kegiatan pengabdian kepada masyarakat. Data awal yang digunakan sebagai dasar pelaksanaan kegiatan diperoleh melalui wawancara untuk mendapatkan informasi secara langsung yang dapat menjelaskan dan menjawab permasalahan secara obyektif. Penggunaan data sekunder berupa studi kepustakaan dengan membaca literatur yang berkaitan serta menunjang penulisan ini.

Tahapan kegiatan yang dilakukan yaitu koordinasi dengan kepala desa dan Puskesmas, selanjutnya tim pengabmas menyampaikan rencana pelaksanaan kegiatan untuk kelompok sasaran. Tim pengabmas menjelaskan secara detail rincian dan jadwal kegiatan kepada kepala desa. Tahap berikutnya adalah Pelatihan Deteksi Dini Stunting kegiatan pada tanggal 12 September 2021 dan diikuti oleh kader posyandu desa Sidodadi sebanyak 14 orang. Selanjutnya tahapan Monitoring dan Observasi Pendampingan Pelaksanaan RTL berupa kegiatan pendampingan kader, diakhiri dengan tahapan Evaluasi hasil pelaksanaan implementasi kader bersama kepala desa dan presentasi hasil kegiatan, sosialisasi dan advokasi kepada kepala desa dan Puskesmas

\section{HASIL DAN PEMBAHASAN}

\subsection{Persiapan}

Tahap pertama ini merupakan tahap persiapan yang diawali dengan pengurusan izin, advokasi, serta koordinasi dengan mitra diantaranya adalah Puskesmas Hanura dan Desa Sidodadi. Selanjutnya dilakukan identifikasi sasaran yaitu kader yang kemudian akan diikutsertakan dalam pelatihan. Kemudian perlu dilakukan pendekatan awal pada kader dan perangkat desa sehingga mereka tidak merasa asing dengan tim pelaksana kegiatan. Pendekatan ini dilakukan sekaligus pada studi awal dengan cara mengunjungi para kader dan perangkat desa di rumahnya dan mengajak mereka berbincang-bincang untuk timbul rasa dekat satu dengan yang lainnya. 
Kegiatan berikutnya adalah pembuatan media pelatihan, modul deteksi dini stunting, instrument atau tools pelatihan serta menyusun strategi dan bentuk/metode pelatihan yang akan digunakan.

\subsection{Pelatihan}

Kegiatan pada tahap 2 berupa pelatihan dan penyusunan rencana tindak lanjut (RTL). Kegiatan pelatihan dilakukan secara terstruktur pada 14 kader posyandu di desa Sidodadi. Sebelum pelaksanaan pelatihan terlebih dahulu dilakukan pre-test terhadap peserta pelatihan untuk mengetahui tingkat pengetahuan tentang stunting yang dimiliki oleh kader. Kemudian dilanjutkan dengan pelaksanaan pelatihan mengenai stunting dan cara mendeteksi dini stunting dengan menggunakan metode pembelajaran orang dewasa (Adult Learning), yaitu suatu metoda yang disesuaikan dengan latar belakang kader seperti keterbatasan pendidikan pada kader dan selama pelatihan peserta pelatihan berhak untuk didengar dan dihargai pengalamannya, dipertimbangkan setiap ide dan pendapat sejauh berada didalam konteks pelatihan dengan melakukan learning by doing dan belajar atas pengalaman (Learning by experience).

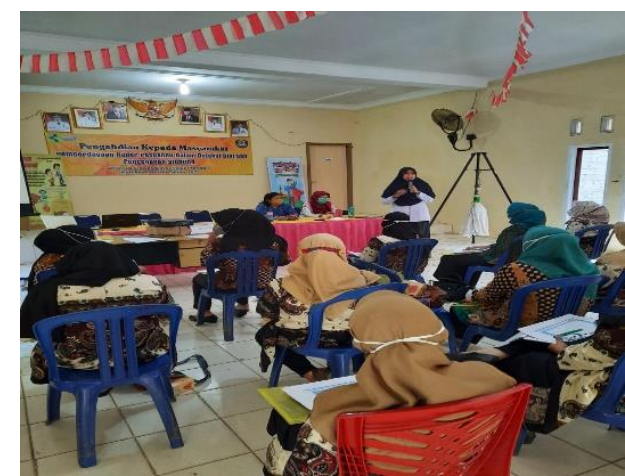

Gambar 1. Kegiatan Pelatihan Kader Dalam Deteksi Dini dan Pencegahan Stunting

Metode penyampaian materi dilakukan secara interaktif dan partisipatif dengan menggunakan berbagai media audio visual yang menarik, ceramah, diskusi kelompok, roleplay (bermain peran) dan simulasi. Pada akhir materi, peserta pelatihan diminta untuk membuat Rencana Tindak Lanjut (RTL) sederhana berupa hal apa saja yang akan mereka lakukan setelah mendapatkan materi pelatihan. Setiap peserta diharapkan melakukan pendeteksian dan promosi tentang pencegahan stunting ini sekurang-kurangnya pada 2 balita atau warga yang ada disekitar tempat tinggalnya. Setelah pelaksanaan pelatihan, kemudian dilakukan post-test. Setelah pelatihan dilakukan, terjadi peningkatan pengetahuan dan rata-rata hasil post-test.

Tabel 1. Perubahan Tingkat Pengetahuan Kader Sebelum danSesudah Pelatihan Kader

\begin{tabular}{lccc}
\hline \multicolumn{1}{c}{ Statistik } & Pretest & Postest & $\boldsymbol{p}_{\text {-value }}$ \\
\hline Mean & 66,25 & 91,67 & \\
Standar deviasi & 14,69 & 8,68 & 0,000 \\
Minimum-maksimum & $50-90$ & $80-90$ & \\
\hline
\end{tabular}

*Paire t-test

Pelatihan yang dilakukan dapat meningkatkan pengetahuan kader tentang deteksi dini dan pencegahan stunting sebesar 25,42 poin dari 66,25 menjadi 91,67. Hasil uji T diperoleh $p$ value $=0,000$ artinya secara statistik ada perbedaan yang signifikan tingkat pengetahuan antara sebelum dan sesudah pemberian pelatihan.

\subsection{Monitoring dan Observasi Pendampingan Pelaksanaan RTL}

Setelah pelatihan, dilakukan pendampingan terhadap kader untuk melihat apakah mereka mempraktekkan materi yang telah diberikan dalam pelatihan. 


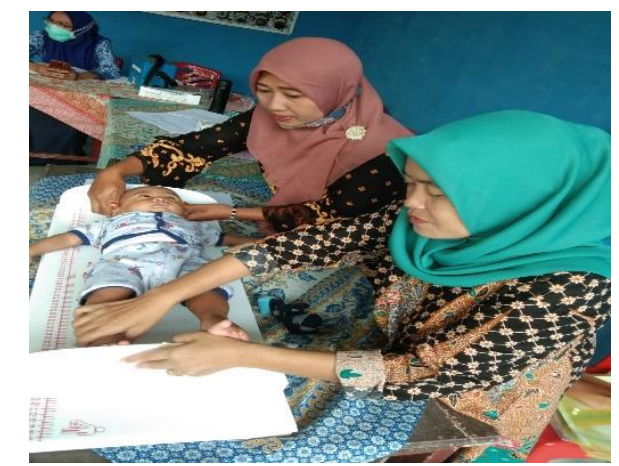

Gambar 2. Monitoring dan Observasi Pendampingan Rencana Tindak Lanjut Pelatihan

Saat pendampingan, setiap kader dikunjungi ke rumahnya dan diminta untuk menceritakan pengalamannya selama deteksi dini dan sosialisasi tentang stunting kepada ibu balita. Berdasarkan dari cerita kader maka dapat disimpulkan apa saja yang menjadi kekurangan serta kendala yang dialami kader disaat melakukan sosialisasi stunting. Selain pendampingan langsung, tim pengabdian masyarakat membentuk sebuah Whatsapp Group sebagai ajang diskusi dengan para kader yang sudah dilatih. Pada umumnya, peserta mensosialisasikan stunting pada kegiatan Posyandu, kelas Ibu hamil, dan di RT tempat tinggal masing-masing peserta. Berikut ini adalah hasil pelaporan kader sebagai tindak lanjut pelatihan:

Tabel 2. Pelaksanaan RTL Oleh Kader Posyandu

\begin{tabular}{ccccc}
\hline $\begin{array}{c}\text { Nama Bayi } \\
\text { dan Jenis } \\
\text { Kelamin }\end{array}$ & Tanggal lahir & $\begin{array}{c}\text { Berat } \\
\text { Badan saat } \\
\text { ini (kg) }\end{array}$ & $\begin{array}{c}\text { Panjang } \\
\text { Badan (cm) }\end{array}$ & $\begin{array}{c}\text { Status Gizi PB } \\
\text { menurut umur } \\
\text { (PB } / \mathbf{U})\end{array}$ \\
\hline Af (P) & $17-07-2020$ & 9,1 & 73 & Normal \\
Yl (P) & $15-02-2020$ & 8,8 & 73 & Pendek \\
Nf (L) & $19-10-2019$ & 12 & 83 & Pendek \\
Ft(P) & $13-07-2019$ & 10,5 & 83,5 & Normal \\
Qi (P) & $24-08-2020$ & 10 & 76,6 & Normal \\
Al (L) & $20-01-2021$ & 6,7 & 66,8 & Normal \\
Az (P) & $15-05-2019$ & 11,2 & 85 & Normal \\
Ra (P) & $17-11-2019$ & 10 & 90 & Normal \\
Za (L) & $07-06-2020$ & 10,9 & 80,1 & Normal \\
Sh (P) & $06-08-2020$ & 10 & 73,9 & Normal \\
Na (P) & $11-11-2020$ & 8,5 & 73,1 & Normal \\
Si (P) & $10-05-2020$ & 8,3 & 72,5 & Pendek \\
Ci (P) & $10-10-2020$ & 7,8 & 70,4 & Normal \\
Re (L) & $27-07-2020$ & 10 & 75,5 & Normal \\
Oc (P) & $10-06-2020$ & 8 & 71 & Sangat pendek \\
Gi (L) & $23-03-2020$ & 10,50 & 81,80 & Normal \\
Az (P) & $28-09-2019$ & 10,35 & 77,30 & Pendek \\
Da (L) & $06-05-2020$ & 10,80 & 78,30 & Normal \\
Sa (P) & $04-09-2020$ & 9,50 & 69,50 & Pendek \\
Ra (L) & $24-04-2020$ & 10,20 & 74,30 & Pendek \\
Qo (P) & $19-03-2020$ & 8,70 & 80,80 & Normal \\
Nu (P) & $13-11-2018$ & 17,20 & 98,00 & Normal \\
Ab (P) & $20-11-2020$ & 7,30 & 69,00 & Normal \\
Na (P) & $31-08-2020$ & 10,70 & 73,00 & Normal \\
Da (P) & $12-03-2020$ & 9,10 & 74,50 & Pendek \\
Ra (P) & $22-11-2020$ & 9,00 & 75,00 & Normal \\
Na (P) & $11-04-2019$ & 10,60 & 84,50 & Normal \\
Ah (L) & $03-07-2019$ & 13,00 & 87,60 & Normal \\
\hline & & & &
\end{tabular}




\subsection{Evaluasi}

Evaluasi dilakukan untuk melihat hasil pelaksanaan pelatihan dan implementasi kader yang sudah dilakukan. Evaluasi ini dilakukan bersama dengan mitra di rumah kepala desa Sidodadi dan hasil evaluasi adalah kader sudah mampu melakukan deteksi dini stunting dan perlu dilakukan kegiatan yang sejenis terutama pada peningkatan kapasitas kader dan diharapkan program ini selanjutnya bisa diteruskan dengan rutin. Kegiatan yang disepakati antar tim pengabmas dan mitra adalah pelatihan kader posyandu dalam membuat MP-ASI berbahan pangan lokal.

\subsection{Keberlanjutan}

Tim pengabmas melakukan presentasi dan sosialisasi hasil kegiatan ke pihak desa dan Puskesmas Hanura. Selain itu tim pengabmas melakukan advokasi agar kegiatan ini dapat diterima menjadi bagian dari kegiatan yang bisa diterapkan di desa Sidodadi dan seluruh desa diwilayah kerja Puskesmas Hanura. Hasil dari sosialisasi dan advokasi adalah pelatihan deteksi dini akan menjadi bagian dari kegiatan Desa Sidodadi dan Puskesmas. Harapan desa Sidodai dan puskesmas agar tim pengabmas dapat selalu bermitra dalam pelaksanaan kegiatan yang sejenis.

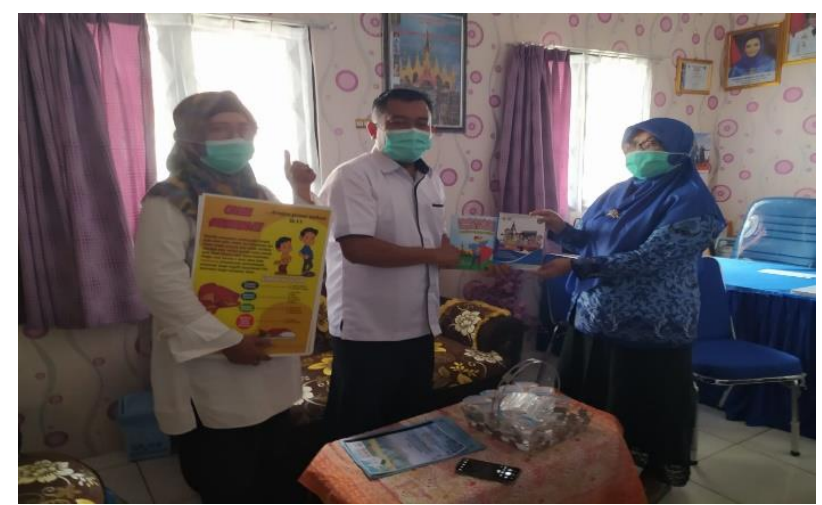

Gambar 3. Presentasi, Sosialisasi, dan Advokasi Ke Pihak Puskesmas Hanura

\section{KESIMPULAN}

Berdasarkan kegiatan yang telah dilakukan dapat disimpulkan bahwa kader posyandu telah meningkat pengetahuan dan kesadaran mengenai stunting, mampu melakukan deteksi kejadian stunting dengan menggunakan KMS dan Grafik Pertumbuhan WHO serta mampu mengedukasi masyarakat tentang pencegahan stunting. Diharapkan kegiatan pemberdayaan kader posyandu dalam deteksi dini stunting sebaiknya dilakukan secara berkesinambungan dengan bekerja sama bersama pihak-pihak terkait, sehingga diharapkan memberikan kontribusi atas terwujudnya peningkatan derajat kesehatan masyarakat pada umunya dan anak pada khususnya. Perlunya dilakukan kegiatan yang sejenis dalam meningkatkan kapasitas kader terutama dalam Pemberian makanan bayi dan anak yaitu Pelatihan Pembuatan MP-Asi Berbahan Pangan Lokal.

\section{UCAPAN TERIMA KASIH}

Penulis mengucapkan terima kasih kepada Direktur Politeknik Kesehatan Tanjung Karang dan Pusat Penelitian dan Pengabdian Kepada Masyarakat (PPM) Politeknik Kesehatan Tanjung Karang yang telah memberi dukungan financial juga tim pengabdian kepada masyarakat jurusan gizi terhadap kegiatan ini sehingga terlaksana dengan baik dan lancar. 


\section{DAFTAR PUSTAKA}

Bappenas. (2019). Percepatan Penurunan Stunting Langkah Strategis Dalam Pembangunan Manusia Berkualitas. Materi disampaikan oleh Direktur Kesehatan dan Gizi Masyarakat pada MUNAS XVI ISMKMI, Makassar, 02 Maret 2019.

Kementerian Kesehatan RI. (2013). Hasil Riset Kesehatan Dasar 2013. Jakarta

Kementerian Kesehatan RI. (2018). Hasil Riset Kesehatan Dasar 2018. Jakarta

Victora CG, Adair I, Fall C, Hallai PC, Martorell R, Richter I, Sachdev HS. (2008). Maternal and Child Undernutrition Study Group. Maternal and Child Undernutrition: Consequences for Adult Health and Human Capital. Lancet. 371:340-57.

WHO, UNICEF. (2013). Improving Child Nutrition: The achievable imperative for global. 


\section{Halaman Ini Dikosongkan}

